\title{
Asthma diagnosis and treatment - 1017. Prevalence and determinants of allergy and asthma amongst Indian children
}

\author{
Sheetu Singh*, Virendra Singh \\ From 2nd WAO International Scientific Conference (WISC 2012) \\ Hyderabad, India. 6-9 December 2012
}

\section{Background}

Jaipur was one of the centres that participated in the third phase of International study of asthma and allergy in children (ISAAC). The findings of Jaipur centre are highlighted in this paper. Prevalence of symptoms of asthma was assessed in school going children of Jaipur. The effects of traffic pollution and tobacco smoke on the prevalence of asthma were also studied.

\section{Methods}

Schools at various centres were randomly selected. Children of eligible age group were included in the study after confirming with the school records. Two groups of children aged between 6-7 year and 13-14 year were selected and questionnaires were given. Parents of the younger age group children answered the questionnaire. The 13-14 year aged children answered the questions themselves along with an additional video questionnaire. The questionnaire included questions regarding exposure to traffic pollution and environmental tobacco smoke. Bivariate analysis was used to calculate the odds ratio.

\section{Results}

The prevalence of wheeze in past 12 months (current wheeze) in the 6-7 yr age group was $5.43 \%$ and in the $13-14 \mathrm{yr}$ age group was $5.37 \%$. The prevalence of severe asthma was $3.42 \%$ in the $6-7 y$ age group and $2.89 \%$ in the 13-14 yr age group. The proportion of asthmatics with severe asthma was high with $62.94 \%$ in the $6-7 y$ age group and $53.85 \%$ in the older aged children. In the 6-7y age group asthma was significantly associated with environmental tobacco smoke and in the $13-14 y$ age group

Division of Allergy \& Pulmonary Medicine, SMS Medical College \& Hospital, Jaipur, India asthma was associated with traffic pollution. Odds of developing bronchial asthma in the 13-14 y group exposed to traffic pollution was 1.730 (95\% CI: 1.209 to 2.475). Current wheeze was also associated in the 6-7 yr age group with maternal cigarette smoking with odd ratio of 2.627 (95\% CI: 1.781 to 3.875 ) and paternal cigarette smoking with odd ratio of 9.144 (95\% CI: 5.457 to 15.324).

\section{Conclusions}

Environmental tobacco smoke and traffic pollution were associated with high prevalence of asthma amongst school going children of Jaipur.

Published: 23 April 2013

doi:10.1186/1939-4551-6-S1-P17

Cite this article as: Singh and Singh: Asthma diagnosis and treatment -

1017. Prevalence and determinants of allergy and asthma amongst Indian children. World Allergy Organization Journal 2013 6(Suppl 1):P17.
Submit your next manuscript to BioMed Central and take full advantage of:

- Convenient online submission

- Thorough peer review

- No space constraints or color figure charges

- Immediate publication on acceptance

- Inclusion in PubMed, CAS, Scopus and Google Scholar

- Research which is freely available for redistribution
() Biomed Central 